\title{
CARBON STOCK IN SUBTROPICAL NATIVE FORESTS IN A SOUTH AMERICAN PROTECTED AREA
}

\author{
Julian A. Sabattini* ${ }^{\mathbb{D}}$, Rafael A. Sabattini ${ }^{\mathbb{D}}$, Juan C. Cian ${ }^{\mathbb{D}}$, Ivan A. Sabattini \\ National University of Entre Rios, Argentina \\ *e-mail: julian.sabattini@fca.uner.edu.ar
}

Received: 26.06.2020. Revised: 14.02.2021. Accepted: 24.02.2021.

\begin{abstract}
In forests, it is possible to sequester the carbon emitted by industrial activities, although global deforestation has recently increased considerably. Protected Areas make a significant contribution to mitigate negative effects of climate change. In this sense, the aim of this study is to estimate the carbon storage of the different types of subtropical native forests in the Protected Area «Estancia El Caraya» (hereinafter - PA «El Caraya»), located in the Mesopotamian Spinal. The study was carried out in the province of Entre Rios, Argentina. We evaluated the carbon stock in the soil and herbaceous, shrub and tree components of five various environments with native forests as the dominant biome. The soil component represented $81 \%$ of the carbon stock in native forest, while the remaining percentage is distributed in trees $(11 \%)$, shrubs $(6 \%)$, and herbaceous vegetation $(2 \%)$. Native forest of PA «El Caraya» stores $0.974 \mathrm{t} \mathrm{C} \times \mathrm{km}^{-2}\left(3.56 \mathrm{t} \mathrm{CO}_{2} \times \mathrm{km}^{-2}\right), 39.4 \%$ less than the world average in this conservation category. These differences are due to the high heterogeneity of the natural environments in the world due to the very diverse ecological conditions. Proper management practice of subtropical native forests in the Spinal Mesopotamian contributes highly to reduction of carbon in atmosphere. Application of forest management techniques in Protected Areas allows obtaining sustainable forests that maximise the potential of this area.
\end{abstract}

Key words: carbon sink, climate change, ecosystem services, El Caraya, policies public, protected forest, reduction of emissions

\section{Introduction}

The world has serious problems caused alteration of nature by humanity. The rapid and constant increase in the burning of fossil fuels, the increase in deforestation, and the expansion of cultivated areas have caused a radical change in the composition of the atmosphere, fundamentally increasing carbon dioxide $\left(\mathrm{CO}_{2}\right)$ and other gases that cause the known global climate changes. The need to stabilise the carbon (C) content of the atmosphere has been manifested in a series of international and local agreements and policies, such as the Kyoto Protocol and the Treaty of Paris (Bassi et al., 2009). The purpose of these agreements and policies is to reduce emissions of greenhouse gas (GHG), with mechanisms to optimise carbon sinks (Fragoso-López et al., 2017).

During the development of Western Europe, a large part of forest resources was consumed. This was not caused only by the high consumption of wood. One more reason is that forests had given up part of their surface in favour of other uses such as the incorporation of land into agriculture, livestock, urban development, among others. This situation led to a major «energy crisis» in the mid-1700s (i.e. «Industrial Revolution»), which changed the productive, social and economic paradigm, giving rise to western civilisation (Malanima, 2006). From there, the atmospheric $\mathrm{CO}_{2}$ concentration has increased by approximately $30 \%$ mainly due to anthropogenic activity. In America, the mining industry developed in the early days of the conquest and the European colony. It consumed a large amount of forest resources destined for combustion in the smelting furnaces. The forests also gave part of their surface in favour of agriculture and urban development of the growing population (Malanima, 2006). However, the great expansion of the agricultural frontier occurred at the beginning of the XX century (IPCC, 2014).

Anthropogenic GHG emissions have continuously increased in the world in 1970-2010, presenting the highest increase during 2000-2010, being the highest in the history of humanity (IPCC, 2014). Argentina presents the same trend, with an annual growth of $2.15 \%$ average in GHG emission in 1990 2012 (SADSN, 2015). The two main ways to slow down global warming of the planet are: a) to decrease emissions and b) to increase $\mathrm{CO}_{2}$ sequestration in natural systems. Conserving and restoring natural habitats is among the most cost-effective emissions mitigation strategies available. However, while clear synergies exist between the objectives of biodiversity protection and carbon capture, there is a risk that if conservation and climate change mitigation agendas are misaligned, one could easily undermine the other (Roberts et al., 2020). Melillo et al. (2016) indicated that forests, covering $6700000 \mathrm{~km}^{2}$, are the dominant ecosystems in Protected Areas, with grazed rangelands being the second most dominant ecosystem $\left(3000000 \mathrm{~km}^{2}\right)$. In addition, they mention that terrestrial Protected Areas currently function as car- 
bon sinks that sequester about 0.5 petagram $(\mathrm{Pg}) \mathrm{C}$ each year.

One of the alternatives to accumulate $\mathrm{C}$ is through forest ecosystems, by exchanging $\mathrm{C}$ with the atmosphere through photosynthesis and respiration, leading to storage in biomass and in the soil (Taiz \& Zeiger, 1998). Carbon plays a fundamental role in the planet's physicochemical and biological processes throughout its cycle. Carbon capture and emission processes are part of a system of four $\mathrm{C}$ reservoirs (aboveground and radical vegetation, decomposing matter, soils, and forest products), with very different and closely interrelated residence times and associated flows. It is estimated that approximately $50 \%$ of the plant organic matter is C (Brown \& Lugo, 1984; IPCC, 1995). However, various studies showed the variability of carbon content according to species and tree tissue (Francis, 2000; Gifford, 2000; Soares \& Oliveira, 2002). These variables allow estimating and predicting the exchange of $\mathrm{C}$ with the atmosphere, previously knowing the plant biomass and its growth.

Soil is the main source carbon on the Earth surface storing between $1500 \mathrm{Pg}$ and $2000 \mathrm{Pg}$ (Janzen, 2004 ), being the most abundant element in soil organic matter (45-55\%), and, performing an important role in the carbon cycle by capturing two to three times more than atmospheric $\mathrm{CO}_{2}$. Carbon stock in forest ecosystems is carried out by exchanging carbon with the atmosphere through photosynthesis and respiration, maintaining a stock in the phytomass and soil mass (de Petre et al., 2011). In this sense, the carbon inputs to the soil come from various sources such as the litter of the herbaceous, shrub and tree plant species, as well as the death and decomposition of plant roots that makes up the system. However, outputs are mainly determined by the oxidation of soil organic matter in the form of $\mathrm{CO}_{2}$ and losses by degradation or ecosystem deforestation. Soil organic matter is very sensitive to changes in land use. It has a very complex and heterogeneous composition, generally mixed or associated with the mineral constituents of the soil (Jackson, 1964).

Forests have the possibility of carbon stock emission by industrial activities. Nevertheless, it is known that global deforestation has recently increased considerably. Currently, forests store around 800 gigatons (Gt) of C (Brown, 1998). Estimates indicated that by 2050 they could sequester up to an additional $87 \mathrm{Gt} \mathrm{C}$ (Metz et al., 2001). It was assessed that in 2000-2007, the carbon sequestration rate of the global forests averaged $4.1 \mathrm{Gt} \mathrm{C} \times$ year $^{-1}$ (Pan et al., 2011) corresponding 30\% of the emissions of fossil fuels in 2010 (IPCC, 2014). Native forests represent $30 \%$ of land cover (FAO, 2007) and have decreased in recent years (Hansen et al., 2013). South America had the highest loss of native forests, estimated at $40000 \mathrm{~km}^{2}$ during 2000-2005 (FAO, 2007). In Argentina, $70 \%$ of forests have been lost in the last 80 years due to the advance of agriculture (Cozzo, 1979; FAO, 2009). Particularly, in the early XX century, the province of Entre Ríos had $25000 \mathrm{~km}^{2}$ of native forests. A reduction of $40 \%$ has recently been determined (Sabattini et al., 2015a). These changes in land use and coverage have caused one third of anthropogenic $\mathrm{CO}_{2}$ emissions during 1850-1980 (Pardos, 2010).

Properly managed forest systems allow storaging more carbon than other terrestrial ecosystems (Dixon et al., 1994), contributing to reduce the GHG. For this reason, the importance of the conservation and protection of native forests increases the production efficiency of ecosystem goods and services (Franquis $\&$ Infante, 2003). Protected forests in the world are proposed as a potentially profitable strategy to avoid deforestation and degradation (Nauclér \& Enkvist, 2009; Soares-Filho et al., 2010; Venter et al., 2016; Melillo et al., 2016; Nogueira et al., 2018). There are several studies aimed to determine the carbon sequestration capacity in forest ecosystems. Various studies in Argentina showed the potential for carbon storage in forest biomass in various ecoregions (Davis et al., 2003; Gasparri \& Manghi, 2004; Gasparri et al., 2008; Manrique et al., 2009; Peri et al., 2010, 2013; Vega \& Martiarena, 2010; Risio Allione, 2012; Manrique \& Franco, 2012; Ontiveros et al., 2015; Barth et al., 2016; Frangi et al., 2016; Fernandez et al., 2018; Sione et al., 2018; Urdapilleta, 2018).

For these reasons, conserving native forests is a priority to halt the biodiversity loss, mitigate climate change, and achieve sustainable development goals (Watson et al., 2018). These actions are encouraged through carbon-based redistribution mechanisms for ecosystem services (Baker et al., 2010). In this sense, the Protected Area «Estancia El Caraya» (hereinafter - PA «El Caraya») has a vision committed to the conservation and care of the environment, as it allocates a remarkable area of native forests typical to the Argentine Spinal (Sabattini \& Sabattini, 2019). Recent studies described the conservation status of the most representative environments (Sabattini R. et al., 2019) and the associated fauna (Muzzachiodi \& Sabattini, 2019). In this sense, the aim of this study is to estimate the carbon stock of various types of subtropical native forests in the PA «El Caraya» located in the Mesopotamian Spinal, and to contribute mitigation the effects of global climate change. 


\section{Study area}

The study was carried out in the PA «El Caraya», located in the centre-north of the province of Entre Ríos, Argentina (30.63 $\left.\mathrm{S}, 58.79^{\circ} \mathrm{W}\right)$. It has an area of $104 \mathrm{~km}^{2}$ (Fig. 1). According to the Köppen classification, the area corresponds to a humid subtropical climate, characterised by hot and humid summers and cool winters. Rojas \& Saluso (1987) indicated that this region has a humid temperate climate, typical of plains, with an average annual temperature of $18.9^{\circ} \mathrm{C}$ (Soil Mapping Plan, 1986). The average annual rainfall is $1300 \mathrm{~mm}$, with rains concentrated between October and March. However, in the last decade there have been notable changes in the distribution of seasonal and annual rainfall (Sabattini \& Bongiovanni, 2019).

Soils are imperfectly drained because of the irregular surface that fluctuates from flat to very gently undulating areas. Rainwater is accumulated on the surface when rains are excessive (Sabattini et al., 2015b). They have a loam epipedon (below $10 \mathrm{~cm}$ ), which is followed by a waterproof horizon and is impenetrable by roots (Soil Mapping Plan, 1986). The PA «El Caraya» presents two main soil types: Vertisols and Alfisols. Vertisols are developed on sedi- ments of lake-marsh origin, also called calcareous clay silts of the «Hernandarias Formation». The most important characteristics of these soils are a uniform dark colour, the formation of cracks, and the presence of abundant intercepted slickensides. They have a high capacity to store water, but its proportion available for plants is low due to other physical limitations, including poor aeration, high resistance to root penetration, and a shallow rooting depth (Cerana et al., 2005). They have high structural stability under natural conditions due to the contribution provided by colloids. But these can be severely affected by inadequate management that causes the loss of organic matter and water erosion (Wilson, 2017). Instead, Alfisols are originated from calcareous silts of the same formation but in flat relief. The hydromorphic processes are notably accentuated. Therefore, the soils are characterised by abundant mottled and ferromanganesiferous concretions throughout the profile. The epipedon is shallow $(7-10 \mathrm{~cm})$ with $20-27 \%$ clay. Both orders present a dense, dark subsurface horizon, with a clay-silty texture, with clay content between $40-50 \%$ and low permeability. This means an obstacle to the normal development of the root system of plants (Soil Mapping Plan, 1986).
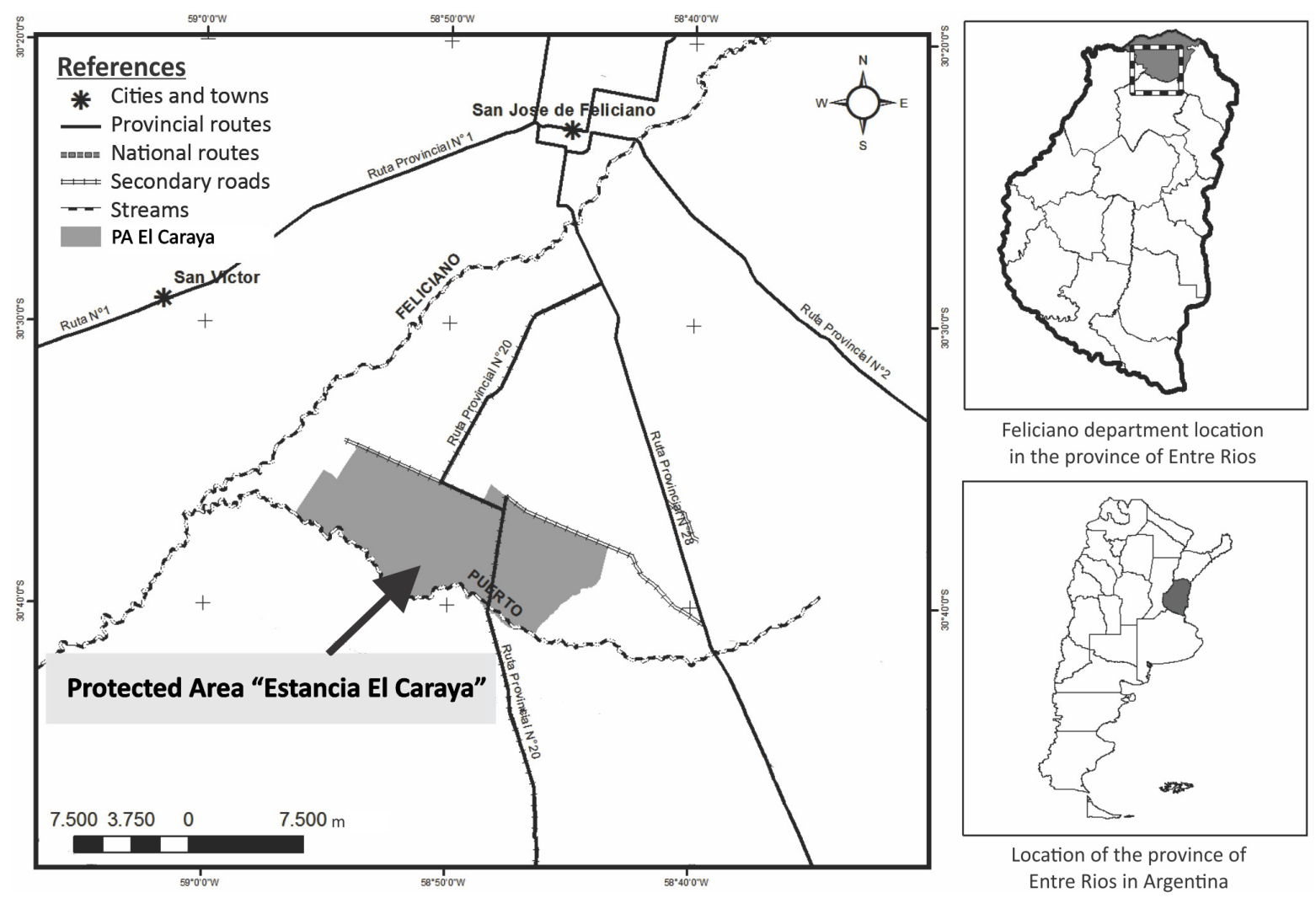

Fig. 1. Location of the Protected Area «Estancia El Caraya» of the province of Entre Ríos, Argentina. 
According to Oyarzabal et al. (2018), the study area corresponds to the Spinal Phytogeographic province, characterised by xerophilous forests dominated by Prosopis nigra (Griseb.) Hieron., P. affinis Spreng., and Vachellia caven (Molina) Seigler \& Ebinger. The native forests are heterogeneous, due to the physiognomy and structure of the tree layer, the shrub layer development, the soil diversity, and the hydrographic network crossing through this area. In general, the current state of these ecosystems is characterised by the location within the plant succession. Here, the dominant secondary forests extend in the study area with $20 \%$ to $25 \%$ plant cover. This corresponds to intermediate stages of the plant succession in which diversity improves, but has not yet stabilised (Sabattini et al., 1999; Sabattini et al., 2015a). Studies in PA «El Caraya» indicate the presence of Celtis ehrenbergiana Gillies ex Planch., Geofroea decorticans (Gill. Ex Hook. \& Arn.) Burkart, Eugenia cisplatensis Cambess. and Parkinsonia aculeata L., as companion species to the tree stratum, as well as numerous juvenile individuals of $V$. caven and $P$. affinis, dried and standing dead. In addition, there are other sites represented by closed forests with a shrub cover between $32.5 \%$ and $62.5 \%$, with the dominant species Baccharis punctulata L., accompanied by Eupatorium buniifolium Hook. \& Arn., E. laevigatum Lam. and Aloysa grattisima (Gillies \& Hook. ex Hook.) Tronc. The condition of the natural grassland responds to a very good condition for livestock production, being very palatable, of good size and vigour (Sabattini et al., 2003); species of the genera Nassella E.Desv., Bothriochloa Kuntze, Chloris Sw., and Paspalum L. are also dominating (Sabattini et al., 2015a).

\section{Collection and analysis of information}

Native forests of PA «El Caraya» has five contrasting environments characterised by Sabattini et al. (2015b), based on their structure, floristic composition and physiognomy of the plant components. In each one, the carbon storage in the soil and vegetation types (herbaceous, shrub and tree) has been estimated. Sabattini et al. (2015b) identified five environment types contrasting natural native forests dominated by the presence of the tree component: I) Garat with vegetation dominated by high open native forest; II) Association $\mathrm{A}^{\circ}$ Quebracho-Garat vegetation dominated by low and closed native forest; III) Association $\mathrm{A}^{\circ}$ Quebracho-Grecco with vegetation dominated by high and closed native forest; IV) Grecco with vegetation dominated by low and closed native forests of sectors Trithrinax campestris (Burmeist.) Drude \& Griseb. and Aspidosperma quebracho-blanco Schltdl.; V)
Arroyo Feliciano dominated by riverside forest with shrub jungle. The native forests of each environment are close to the climax, considering the successional stages, based on thier structural, physiognomic and floristic components (Sabattini \& Sabattini, 2018).

\section{Carbon sequestered in soil}

A baseline of Soil Organic Carbon (SOC) stocks can be estimated by physical sampling and measurement, modelled estimation, or assumed values (FAO, 2018). In this study, we used the soil mapping units associated with each environment carried out by Sabattini et al. (2015b). In addition, we used the results obtained in Sabattini et al. (2015b) for variables required in the calculation such as: bulk density by the cylinder method (Al-Shammary et al., 2018), thickness of the sampling horizon and the percentage of organic carbon with a Walkey-Black Method (Nelson \& Sommers, 1982). In this study, 17 surface soil samples (00-12), distributed among environments throughout the PA «El Caraya», were extracted, based on the edaphological description of the entities mentioned with the limitations and physical restrictions of the soils. In each sample, the SOC was determined in the soil fraction passing through the 2-mm sieve (Whitehead et al., 2012), which is the fine earth fraction. For inventory purposes, the measurement of SOC in the fine soil fraction $(<2 \mathrm{~mm})$ should be adequate. In addition, the coarse mineral fraction $(>2$ $\mathrm{mm}$ ) of the soil was determined to estimate the SOC stock, and in all measures it was zero. SOC stocks should be reported for the 0-30 cm layer to comply with IPCC recommendations, and an appropriate error and uncertainty should be reported. However, since in this case data are obtained from the first 12 $\mathrm{cm}$ of depth, a standardised extrapolation was carried out as mentioned in the bibliography (FAO, 2018), and SOC stocks was estimated using this formula for $30 \mathrm{~cm}$ depth increment (i):

$$
S O C_{i}=O C_{i} \times \text { BDfine }_{i} \times\left(1-v G_{i}\right) \times t_{i} \times 0.01,
$$

where $\mathrm{SOC}_{i}=$ soil organic carbon stock $\left(\mathrm{t} \mathrm{C} \times \mathrm{km}^{-2}\right)$ of the depth increment $\mathrm{i} ; \mathrm{OC}_{\mathrm{i}}=$ organic carbon content $\left(\mathrm{mg} \mathrm{C} \times \mathrm{g} \mathrm{soil}^{-1}\right)$ of the fine soil fraction $(<2 \mathrm{~mm})$ in the depth increment $i_{\text {; }}$ BDfine $_{i}=$ the mass of the fine soil per volume of fine soil of the depth increment i ( $\mathrm{g}$ fine earth $\times \mathrm{cm}^{-3}$ fine earth $=$ dry soil mass (in g) - coarse mineral fragment mass (in g)) / (soil sample volume (in $\mathrm{cm}^{3}$ ) - coarse mineral fragment volume (in $\left.\left.\mathrm{cm}^{3}\right)\right) ; \mathrm{vG}_{\mathrm{i}}=$ the volumetric coarse fragment content of the depth increment $\mathrm{i} ; \mathrm{t}_{\mathrm{i}}=$ thickness (depth, in $\mathrm{cm}$ ), of the depth increment $\mathrm{i} ; 0.01=$ conversion factor for converting $\mathrm{t} \mathrm{C} \times \mathrm{cm}^{-2}$ to $\mathrm{C} \times \mathrm{km}^{-2}$. 


\section{Carbon stored in aboveground vegetation}

The aboveground vegetation biomass was estimated in three vegetation types presented in each environment, namely tree, shrub and herbaceous. Tree biomass ( $\mathrm{kg}$ dry matter $\times \mathrm{km}^{-2}$ ) was evaluated using 54 rectangular plots of $500 \mathrm{~m}^{2}$ each (Fig. 2). They are geo-referenced with their central points and were distributed in the PA «El Caraya» using the internal roads by means of a preferential method (Matteuci \& Colma, 1982) in all environments (Sabattini et al., 2015b). In each plot, all the adult plant species were identified taking into account those with more than $10 \mathrm{~cm}$ in diameter at breast height (DBH). Plants having DBH less than $10 \mathrm{~cm}$ were not taken into account. Three variables were recorded: a) the DBH at $30 \mathrm{~cm}$ height using a manual caliper; b) the total crown height using a Suunto clinometer (h); c) the horizontal coverage of the crown of each tree with respect to the ground using a tape measure $(\mathrm{Ca})$. Then, estimates of aboveground biomass (B) per area were made using local allometric models (Table 1), considering the density of the following dominant species: Vachellia caven, Prosopis affinis, and P. nigra.
The biomass of the shrub and herb strata were obtained through available information from the PA «El Caraya» (Sabattini et al., 2003, 2013, 2014; Sabattini J. et al., 2015b, 2019). In both cases, the herb was cut $5 \mathrm{~cm}$ above the ground. Then the fresh herb was weighed with a one-tenth precision portable scale. Subsequently, it was dried with a forced air oven at $80^{\circ} \mathrm{C}$ for $48 \mathrm{~h}$. The shrub layer is dominated by Baccharis spp., , accompanied by herb species like Eryngium horridum Malme and Melica macra Nees (Sabattini J. et al., 2019). Given that the shrub layer coverage is heterogeneous in each of the environments according to Sabattini et al. (2015b), and only information measured in the field is available in certain environments and on shrub expansion level (Fig. 2), the value of shrub biomass for the rest of the classes was estimated taking into account the percentages of their coverage in each class as follows: Class $+(<5 \%)$, Class $1(5$ $15 \%)$, Class $2(25-50 \%)$, Class $3(50-75 \%)$, and Class $4(>75 \%)$. The same criteria were used to estimate the biomass of the herbaceous plants, considering that it can be reduced by an increase in shrub cover, according to Sabattini et al. (2014).

Table 1. Allometric models of dominant tree species used to estimate the biomass of the tree layer in each environment

\begin{tabular}{lll}
\hline \multicolumn{1}{c}{ Tree species } & \multicolumn{1}{c}{ Allometric models } & \multicolumn{1}{c}{ Reference } \\
\hline Vachellia caven & $\mathrm{Ln} \mathrm{B}=-3.40828+2.17836 \mathrm{Ln}(\mathrm{DBH})+0.95212 \mathrm{Ln}(\mathrm{h})$ & Lucero Ignamarca et al., 2018 \\
Prosopis affinis & $\mathrm{Ln} \mathrm{B}=-2.01+0.02 \mathrm{Ca}+1.73 \mathrm{Ln}(\mathrm{DBH})+0.82 \mathrm{Ln}(\mathrm{h})$ & Sione et al., 2019 \\
Prosopis nigra & $\mathrm{B}=32.0443+0.0545 \mathrm{DBH}^{2} \mathrm{~h}$ & Gaillard de Benitez et al., 2014 \\
\hline
\end{tabular}

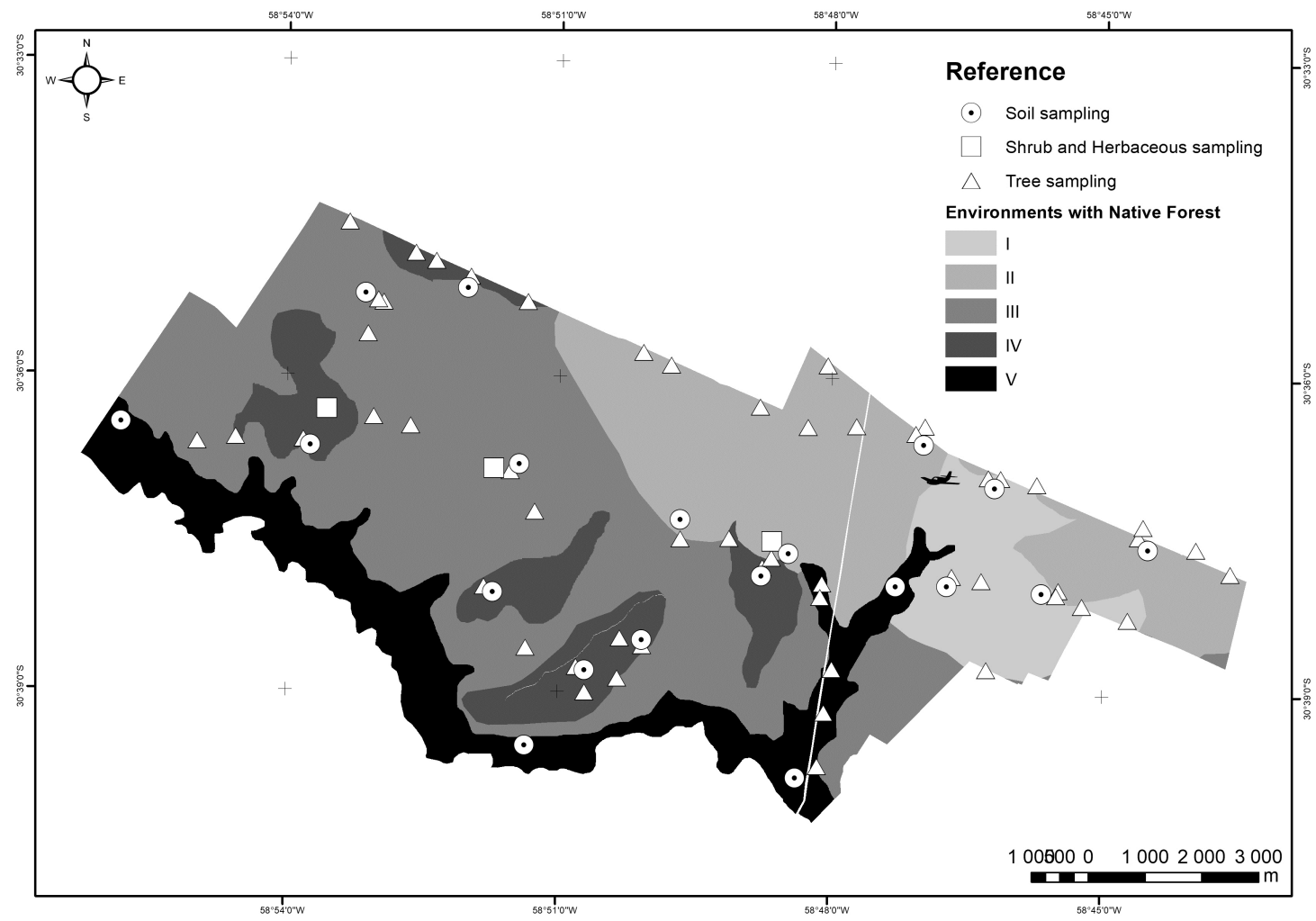

Fig. 2. Location of the soil sampling sites (Sabattini et al., 2015b), shrub and herbaceous species (Sabattini et al., 2003, 2013, 2014; Sabattini J. et al., 2015b, 2019) and tree species in the Protected Area «El Caraya». 
For all vegetation types, the carbon stock $\left(\mathrm{t} \mathrm{C} \times \mathrm{km}^{-2}\right)$ was determined by multiplying the biomass value by the coefficient 0.5 . It is used as a predetermined value without differentiating between species (Brown \& Lugo, 1984; IPCC, 1995), by ignoring the variation of the carbon fraction between plant species, organs or components of plants and life forms, which may generate biases in the estimate (Martin \& Thomas, 2011). However, for the purposes of the estimation its use for this work is valid. Then, the carbon values were converted to $\mathrm{CO}_{2}$ multiplying by 3.67 , according to their stoichiometric equivalence (IPCC, 1995).

\section{Results \\ Carbon sequestered in soil}

Table 2 shows the results of the total carbon stock in the soil fraction by environments in the PA «El Caraya». The storage capacity in soil was $29.173 \mathrm{t} \mathrm{CO}_{2}$, where the $\mathrm{A}^{\circ}$ Quebracho-Grecco Association contributed $44.9 \%$ due to its extension. In general, the dominance of soils was the Order Vertisol and Alfisol. They generally restricted aptitude for various alternatives for agricultural and livestock use, with limitations such as water erosion, high contents of expandable clays, impeded internal drainage and poor surface drainage in the flat sectors with waterlogging. The soils of the Garat environment were Vertic Argiuacuol, with mollic epipedon and a surface horizon with a higher organic carbon content compared to the rest of the environments present in the PA «El Caraya». This situation generates conditions of good natural fertility. On the other hand, the associations, showing dominance of vertically occurring Ocracualf soils, decreased their percentage of organic carbon. Finally, near to the stream El Puerto, there is an environment with jungle forests made up of little evolved soils of alluvial layers belonging to the Haplacuept Subgroup. The layers in depth present a marked variability of texture (silty, clayey and / or sandy), but in those soils it is common to be more silty However, the clay content increases in the deeper horizons. After the flood, plant remains are left for its decomposition causing a slight increase in the percentage of organic carbon, but not enough for carbon accumulation due to its poor surface structure and intense leaching.

\section{Carbon stored in aboveground vegetation}

The global results indicate that the $\mathrm{PA} \ll \mathrm{El} \mathrm{Ca}-$ raya» is dominated by three tree species, namely Prosopis affinis (47\%), Vachellia caven (45\%), and Prosopis nigra (3\%). The average tree density is $37400 \pm 14500$ individuals $\times \mathrm{km}^{-2}$ with an average height of $3.85 \mathrm{~m}$. Environment III presented the highest abundance (41 $800 \pm 14400$ individuals $\left.\times \mathrm{km}^{-2}\right)$, while Environment IV is the most restrictive from the edaphic and topographic point of view, being presented by the lowest abundance (35 400 \pm 21200 individuals $\times \mathrm{km}^{-2}$ ). However, Environment II presented less abundance compared to Environment III, while the tree biomass is higher (Table 3), responding to a higher DBH and total tree height. The total $\mathrm{CO}_{2}$ stock of the tree stratum in the PA «El Caraya» is $89.3 \mathrm{t} \mathrm{CO}_{2}$, and, like in the soil carbon stock, Environment III (Association $\mathrm{A}^{\circ}$ Quebracho-Grecco) contributed $43.2 \%$ of the total amount.

The shrub layer of the PA «El Caraya» was heterogeneous in terms of coverage and floristic composition depending on the environment type, dominated by species of the genera Baccharis, Eupatorium and Aloysia. The herbaceous component was presented by dominance of herbaceous species of the genera Nasella, Piptochaetium and Bromus, with various seasonal growth cycles. Considering the cover of the shrub species, Table 4 presents the estimates of the stored carbon stock in this layer, and its estimation of the herbaceous layer for each shrub level in each environment.

Table 5 shows a summary of the unit carbon stock per $1 \mathrm{~km}^{2}$ of each component (soil and vegetation) by environment. The difference in unitary carbon stock between the opposite environments was $48 \%$. Environment I stores the highest carbon stock $\left(1.219 \mathrm{t} \mathrm{C} \times \mathrm{km}^{-2}\right)$, while Environment IV stores $0.812 \mathrm{t} \mathrm{C} \times \mathrm{km}^{-2}$. These changes depend on the successional position, which varies in the trophic and physiognomic structure.

Table 2. Estimation of carbon storage in the soil at $30 \mathrm{~cm}$ to depth by environment in the Protected Area «El Caraya»

\begin{tabular}{|c|c|c|c|c|c|c|}
\hline Environment & $\begin{array}{c}\text { Surface } \\
\left(\mathrm{km}^{2}\right)\end{array}$ & $\begin{array}{c}\text { BDfine }_{i}^{*} \\
\left(\mathrm{t} \text { soil } \times \mathrm{m}^{-3}\right)\end{array}$ & $\begin{array}{c}\mathrm{OC}_{\mathrm{i}}{ }^{*} \\
(\mathrm{mg} \mathrm{C} \times \mathrm{g} \text { soil })\end{array}$ & $\begin{array}{c}\mathrm{SOC}_{\mathrm{i}} \\
\left(\mathrm{t} \mathrm{C} \times \mathrm{km}^{-2}\right)\end{array}$ & $\begin{array}{l}\text { Total Soil Carbon } \\
\text { (t C) }\end{array}$ & $\begin{array}{l}\text { Total Stock } \\
\left(\mathrm{t} \mathrm{CO}_{2}\right)\end{array}$ \\
\hline I & 8.08 & 1.35 & 2.63 & 1.07 & 860.6 & 3155.6 \\
\hline II & 21.63 & 1.32 & 1.99 & 0.79 & 1704.5 & 6249.9 \\
\hline III & 47.01 & 1.31 & 1.93 & 0.76 & 3565.7 & 13074.0 \\
\hline IV & 11.76 & 1.31 & 1.63 & 0.64 & 753.3 & 2762.2 \\
\hline $\mathrm{V}$ & 15.58 & 1.27 & 1.79 & 0.68 & 1062.5 & 3895.9 \\
\hline
\end{tabular}

Note: *Data from Sabattini et al. (2015b). 
Table 3. Estimation of carbon sequestration in the tree component by environment in the Protected Area «El Caraya»

\begin{tabular}{ccccc}
\hline Environment & Surface $\left(\mathrm{km}^{2}\right)$ & Aboveground biomass $\left(\mathrm{t} \times \mathrm{km}^{-2}\right)$ & Total carbon $(\mathrm{t} \mathrm{C})$ & Total stock $(\mathrm{t} \mathrm{CO})$ \\
\hline I & 8.08 & 0.153 & 1.24 & 4.54 \\
II & 21.63 & 0.373 & 8.06 & 29.57 \\
III & 47.01 & 0.224 & 10.53 & 38.61 \\
IV & 11.76 & 0.215 & 2.53 & 9.28 \\
V & 15.58 & 0.128 & 1.99 & 7.29 \\
\hline
\end{tabular}

Table 4. Estimation of carbon sequestration in the shrub and herbaceous layers by environment in the Protected Area «El Caraya» and shrub expansion level by environment

\begin{tabular}{|c|c|c|c|c|c|c|c|}
\hline Environment & $\begin{array}{c}\text { Shrub expansion } \\
\text { level }\end{array}$ & Surface $\left(\mathrm{km}^{2}\right)$ & $\begin{array}{l}\text { Shrub biomass } \\
\left(\mathrm{kg} \mathrm{DM} \times \mathrm{km}^{-2}\right)\end{array}$ & $\begin{array}{l}\text { Herb biomass } \\
\left(\mathrm{kg} \mathrm{DM} \times \mathrm{km}^{-2}\right)\end{array}$ & $\begin{array}{l}\text { Total shrub carbon } \\
\text { (t C) }\end{array}$ & $\begin{array}{l}\text { Total herbaceous } \\
\text { carbon }(\mathrm{t} \mathrm{C})\end{array}$ & Total stock $\left(\mathrm{t} \mathrm{CO}_{2}\right)$ \\
\hline \multirow{5}{*}{ I } & Class + & 3.44 & 34.8 & 73.1 & 0.060 & 0.1200 & 0.680 \\
\hline & Class 1 & 3.25 & 104.4 & 65.4 & 0.170 & 0.1000 & 1.010 \\
\hline & Class 2 & 1.35 & 174.2 & 57.7 & 0.120 & 0.0400 & 0.570 \\
\hline & Class 3 & 0.03 & 348.1 & 38.5 & 0.001 & 0.0006 & 0.004 \\
\hline & Class 4 & 0.01 & 522.2 & 19.2 & 0.003 & 0.0001 & 0.010 \\
\hline \multirow{5}{*}{ II } & Class + & 9.77 & 34.8 & 37.8 & 0.170 & 0.1800 & 1.300 \\
\hline & Class 1 & 6.83 & 104.4 & 33.8 & 0.360 & 0.1100 & 1.730 \\
\hline & Class 2 & 4.28 & $174.1^{2}$ & $29.8^{1}$ & 0.370 & 0.0600 & 1.600 \\
\hline & Class 3 & 0.57 & 348.1 & 19.9 & 0.100 & 0.0060 & 0.380 \\
\hline & Class 4 & 0.18 & 522.2 & 9.9 & 0.050 & 0.0009 & 0.170 \\
\hline \multirow{5}{*}{ III } & Class + & 11.05 & 26.5 & 74.7 & 0.150 & 0.4100 & 2.050 \\
\hline & Class 1 & 11.49 & $79.6^{2}$ & $66.8^{3}$ & 0.460 & 0.3800 & 3.080 \\
\hline & Class 2 & 14.25 & 132.6 & 58.9 & 0.940 & 0.4200 & 5.000 \\
\hline & Class 3 & 5.78 & 265.2 & 39.3 & 0.770 & 0.1100 & 3.230 \\
\hline & Class 4 & 4.44 & 397.8 & 19.6 & 0.880 & 0.0400 & 3.400 \\
\hline \multirow{5}{*}{ IV } & Class + & 1.61 & $18.2^{2}$ & $21.7^{2}$ & 0.010 & 0.0200 & 0.120 \\
\hline & Class 1 & 1.37 & 54.7 & 19.4 & 0.040 & 0.0100 & 0.190 \\
\hline & Class 2 & 5.58 & 91.2 & 17.1 & 0.250 & 0.0500 & 1.110 \\
\hline & Class 3 & 1.82 & 182.4 & 11.4 & 0.160 & 0.0100 & 0.650 \\
\hline & Class 4 & 1.38 & 273.5 & 5.7 & 0.190 & 0.0040 & 0.710 \\
\hline \multirow{5}{*}{$\mathrm{V}$} & Class + & 1.88 & 18.2 & 15.2 & 0.020 & 0.0100 & 0.110 \\
\hline & Class 1 & 1.72 & 54.7 & 13.6 & 0.050 & 0.0100 & 0.210 \\
\hline & Class 2 & 3.36 & 91.2 & 11.9 & 0.150 & 0.0200 & 0.630 \\
\hline & Class 3 & 3.84 & 182.4 & 7.9 & 0.350 & 0.0200 & 1.340 \\
\hline & Class 4 & 4.78 & 273.5 & 3.9 & 0.650 & 0.0090 & 2.430 \\
\hline
\end{tabular}

Note: annual biomass production data chosen from ${ }^{1}$ Sabattini R. et al. (2019), ${ }^{2}$ Sabattini et al. (2014), ${ }^{3}$ Sabattini et al. (2003). Shrub biomass in Environment I was considered equal to II, and in Environment V equal to Environment IV due to the similarity in the floristic composition (our unpublished data). Regarding the biomass of the herb species in Environment I, it was estimated 30\% higher than in Environment II, and in the case of Environment V, 30\% with respect to Environment IV, considering the grazing times evaluated in the field (Victor M. Dopazo, pers. comm.).

Table 5. Carbon stock $\left(\mathrm{t} \mathrm{C} \times \mathrm{km}^{-2}\right)$ in each component analysed by environment

\begin{tabular}{cccccc}
\hline Environment & Soil & Herbaceous & Shrub & Tree & Total \\
\hline I & 1.070 & 0.034 & 0.044 & 0.077 & 1.219 \\
II & 0.790 & 0.017 & 0.048 & 0.186 & 1.040 \\
III & 0.760 & 0.029 & 0.068 & 0.112 & 0.968 \\
IV & 0.640 & 0.008 & 0.067 & 0.108 & 0.812 \\
V & 0.680 & 0.005 & 0.078 & 0.064 & 0.829 \\
\hline
\end{tabular}

\section{Discussion \\ Carbon sequestered in soil}

In global forests, carbon has been estimated at $861 \mathrm{Pg}$ of which $44 \%$ is stored in the soil, $42 \%$ in aboveground biomass and the remaining $14 \%$ in dead wood and mulch (Pan et al., 2011). Approximately half of the carbon accumulated in forest ecosystems is found in the forest floor and in the ground. This value varies with the biome type. In this study, we found that $73 \%$ of the carbon storage from a subtropical native forest, characteristic of the Mesopotamian Spinal, was concentrated in the surface fraction of the soil (Table 5). On the other hand, the variation in the environments is attributed to the marked differences in the surface that give rise to different physical and chemical characteristics of the soils (Sabattini et al., 2015b). Those environments located in a low topographic position, the vegetation cover is scarce, spatially and temporarily. However, the accumulation of organic matter remains, caused by the hydric erosion of higher topographic zones, is expected (Chagas \& Kraemer, 2018). The results obtained in this study indicate that in environments dominated by jungle forests with patches of grasslands (Environment $\mathrm{V}$ ), the stock stored in soil carbon is less 
compared to higher positions. This situation may be explained by the relocation of the surface organic remains due to the periodic flooding caused by the streams that cross the PA «El Caraya», mainly the «Arroyo Puerto» to the south.

The obtained results are similar to other estimates made in the entire north-central region of Entre Ríos, without conducting a field survey, where the soil stock is $0.35 \mathrm{t} \mathrm{C} \times \mathrm{km}^{-2}$ (Vicente et al., 2011). In other regions to the southeast of the continent, particularly in the Mediterranean area of Chile, the carbon stock in ecosystems of the Espinal dominated by Vachellia caven between 30 to 60 years of age, ranges from $0.57 \mathrm{t} \mathrm{C} \times \mathrm{km}^{-2}$ to $0.62 \mathrm{t} \mathrm{C} \times \mathrm{km}^{-2}$ in the first $20 \mathrm{~cm}$ depth with more than $50 \%$ ground covered by vegetation (Muñoz et al., 2007). In Mexico, the potential for carbon storage in vegetation and temperate forest soils was estimated at $2.00 \mathrm{t} \mathrm{C} \times \mathrm{km}^{-2}$ and $3.27 \mathrm{t} \mathrm{C} \times \mathrm{km}^{-2}$, respectively (Monreal et al., 2005). However, there are no studies on the role of various soil types as a terrestrial carbon reservoir under Mexican temperate forests. On the other hand, global studies estimate that tropical forests store $32 \%$ of carbon in the soil, while temperate and boreal forests store around $60 \%$ of carbon in the soil (Pan et al., 2011). The variability in the percentage of carbon stored in the soil is determined by the physical (texture) and structural factors (particle size composition), the climatic factors (temperature and humidity), the heterogeneity in landscape, the type of cover and plant biomass, the plant species diversity, among other local aspects (Pardos, 2010).

Since forest soils concentrate more carbon accumulated in soil than vegetation, the way in which the land is used can activate the decomposition rate of organic matter, by exceeding that of net primary production, and thus release $\mathrm{CO}_{2}$ into the atmosphere. That is why the care and conservation of these forest resources allow mitigating negative effects on the atmosphere, making the organic carbon content of the soil in the subtropical native forests of Argentina as a good indicator of its sustainable management, similarly to other studies (Houghton, 2003; Hedde et al., 2008). However, it is important to assess the term of carbon stock. This depends on two important factors, namely the accumulation dynamic rate, and the maximum level reached, important to possibly reach the soil saturation level, at which point it does not accumulate more carbon, which depends fundamentally on the time and the soil type (Freibauer et al., 2004).

\section{Carbon stored in aboveground vegetation}

The most important loss variable in native forest is deforestation affecting the ecosystems services, in which the plant matrix is completely lost (Brockerhoff et al., 2017; Mori et al., 2017), fundamentally contributing to a remarkable increase in $\mathrm{CO}_{2}$ emission. The changes in land use in tropical forests have been alarming during 1850-1980, by obtaining an annual rate of $155000 \times \mathrm{km}^{-2} \times$ year $^{-1}$ and causing the emission into the atmosphere of $100 \mathrm{Gt}$ of carbon equivalent to a third of anthropogenic emissions (Pardos, 2010). However, there are two ways to stop and reverse this trend, maintaining the coverage of current native forests, or an increasing in area of planted forests in the world. In temperate regions of Europe and North America, an increase in the mass of planted forests has caused an increase in the equivalent carbon stock between $1 \mathrm{Gt}$ to $3 \mathrm{Gt}$ absorbed annually (Malhi et al., 1999). One aspect to highlight is that PA «El Caraya» have low impact from the clearing, probably due to the geographical location of the studied site, distant from paved routes, which makes insecurity in the activity of extraction of wood for sawmills (Sabattini, 2015; Sabattini et al., 2015a).

For this reason, it represents a native forest area in a very good conservation state. It is possible to affirm that the present vegetation is typical of the Spinal Ecoregion (Oyarzabal et al., 2018). Moreover, tree species characteristic of the genus Prosopis and Vachellia dominate (Wilson \& Sabattini, 2001). Physiognomic, floristic and structural aspects of shrub and herbaceous vegetation show a high similarity with native forest in the province of Entre Ríos (Sabattini et al., 2015a). In general, it is possible to affirm that $11 \%$ of the stock in forest ecosystems is represented by the aboveground layer biomass, while $6 \%$ and $2 \%$ by the shrub and herbaceous layers, respectively (Table 4). In this sense, in a native forest ecosystem in Argentina, 19\% of the carbon stock is represented by vegetation, while the remaining percentage of soil carbon stock. Properly managed forest systems have demonstrated that they can sequester more carbon than other terrestrial ecosystems with various land uses (Dixon et al., 1994).

Several studies demonstrated the capacity of carbon stock in forest ecosystems, particularly in Argentina. Peri et al. $(2010,2013)$ estimated the carbon storage in the aboveground and underground tree component (roots) and soil in 
Nothofagus forests, by concluding that they accumulate a total of almost $45000000 \mathrm{t} \mathrm{C}$, of which around $20 \%$ corresponds to aboveground and root biomass, and approximately the remaining to the soil. In cultivated forests, Vega \& Martiarena (2010) estimated that the carbon in the aboveground biomass stored in 30-yearold Araucaria angustifolia (Bertol.) Kuntze plantations (northern province of Misiones) was $0.61 \mathrm{t} \mathrm{C} \times \mathrm{km}^{-2}$, which would imply an accumulation rate of $0.02 \mathrm{t} \mathrm{C} \times \mathrm{km}^{-2} \times$ year $^{-1}$. In plantations of 18-year-old Grevillea robusta A.Cunn. ex R.Br. (northern Argentina), Barth et al. (2016) reported accumulated values of $1.15 \mathrm{t} \mathrm{C} \times \mathrm{km}^{-2}$ in biomass, which would imply an accumulation rate of $0.064 \mathrm{t} \mathrm{C} \times \mathrm{km}^{-2} \times$ year $^{-1}$ at a density of 7.5 individuals $\times \mathrm{km}^{-2}$. These data highlight the importance of forest systems as carbon sinks (Davis et al., 2003).

At the regional level, estimates of the carbon capture of forest ecosystems are scarce and focus only on trees, i.e. the dominant component of the ecosystem. This study presents novel results in carbon stock considering all the components of a forest ecosystem and under conservation guidelines. Results were obtained in plantations of 14-17 year-old Eucalyptus grandis W.Hill ex Maiden, where it was found that these ecosystems accumulate on average $0.22 \mathrm{t} \mathrm{C} \times \mathrm{km}^{-2}$ in the aboveground biomass (Frangi et al., 2016). Furthermore, recently Sione et al. (2018) have reported that the carbon stored in the aboveground tree biomass of native forests of the Spinal Phytogeographic province was $0.40 \mathrm{t} \mathrm{C} \times \mathrm{km}^{-2}$, which represents a sequestration of $1.47 \mathrm{t} \mathrm{CO}_{2} \times \mathrm{km}^{-2}$. However, these values do not represent all of the native forests in Entre Ríos, and they are based on the tree component only. In our study, the carbon stored in the aboveground tree biomass (Table 5) is below the values of other investigations. This depends on the intrinsic heterogeneity of these ecosystems (Sabattini et al., 1999), mainly on the change in the species abundance, the structural and floristic composition, as well as in the position in the ecological succession. Considering the latter, it has been demonstrated that these native forests with an advanced degree in ecological succession, such as the case of Environment II (Table 5), present not only a higher complexity in their trophic structure, but also a higher capacity to the carbon stock. The increase in biomass and the storage of total organic carbon in ecosystems during the successional processes form fundamental challenges for ecology (Odum, 1969).

\section{Protected areas and their role in carbon capture}

The loss of the global forest heritage is strongly associated with the rapid expansion of industrial, agricultural and forest crops due to the demand for these commodities, but also wildfires are degrading it (Gaveau et al., 2016). Therefore, there are public policy instruments aiming to reduce problems in these ecosystems. For example, in the Amazon biome, only public Protected Areas are not sufficient (Soares-Filho et al., 2006, 2010). In addition, special attention should be paid to conservation initiatives aimed at private landholders, as it has been promoting in PA «El Caraya». A commonly used tool is the incentive to create public or private Protected Areas, as well as management. International agreements support the creation of new Protected Areas through the United Nations Convention on Biological Diversity, where it is recommended that each country should allocate $10 \%$ of its area to the creation of Protected Areas for the biodiversity conservation. However, the global database on Protected Areas indicates that these lands cover only $15.4 \%$ of the global terrestrial area (UNEP-WCMC and IUCN, 2016)

For example, the PA «El Caraya» is a private Protected Area which is approved by Law No. 10532 under the category of Multiple Use Reserve, equivalent to the Category VI proposed by IUCN. This category is defined as «Protected Areas conserving ecosystems and habitats together with associated cultural values and traditional natural resource management systems. They are generally large, with most of the area in a natural condition, where a proportion is under sustainable natural resource management and where low-level non-industrial use of natural resources compatible with nature conservation is seen as one of the main aims of the area». A recent study has estimated the carbon stock of various conservation categories of Protected Areas, by registering the highest priority category (Category 1a) with the highest average carbon stock with respect to the rest of the categories $\left(1.5 \mathrm{t} \mathrm{C} \times \mathrm{km}^{-2}\right)$. This suggests that a high protection status is granted on average to more intact or simply higher biomass forests (Collins \& Mitchard, 2017). However, the second highest protection category had an average 
of $0.87 \mathrm{t} \mathrm{C} \times \mathrm{km}^{-2}$, being less than the lowest protection level of category VI $\left(\mathrm{t} \mathrm{C} \times \mathrm{km}^{-2}\right)$. In this study, it was obtained that on the average of the environments the PA «El Caraya» stores $0.974 \mathrm{t} \mathrm{C} \times \mathrm{km}^{-2}$, namely $17 \%$ less than the world average in this conservation category. Possibly, these differences are of such magnitude because the mean carbon storage of Protected Areas of the same category is reported without mentioning the dominant biome. Therefore, differences are caused by high heterogeneity of the natural environments in the world, due to very diverse environmental conditions.

\section{Conclusions}

Using internationally validated estimation methodologies, it was possible to know the carbon stock of subtropical native forests in South America, on example of the PA «El Caraya». The obtained results presented differences between environment types. They are not caused only by the plant life-form (trees, shrubs and herbaceous plants), but their most important variability depends also on the organic matter content of the soil. Therefore, the relative weight of the soil within the ecosystem was verified, as in other native forests under various climatic and plant conditions.

Proper management practice of subtropical native forests in the Spinal Mesopotamian with correct principles, foundations and objectives does contribute highly to the carbon emission reduction towards the atmosphere. Adequate forest management techniques allow obtaining sustainable systems that maximise the potential. Moreover, the Protected Area presents a considerable surface, where it is possible to carry out a livestock activity under the principles of sustainability. Additionally, it provides the society with hidden ecosystem services mitigating the effects of climate change.

\section{Acknowledgments}

The authors are grateful to the company Las Taperitas S.A. for allowing them to use their facilities to perform the study in the Protected Area and Multiple Use Nature Reserve called Estancia «El Caraya». This study was carried out in the framework of research and development project UNER-PID No. 2196 «Ecological succession of a native forest intervened in the Spinal Ecorregion».

\section{References}

Al-Shammary A.A.G., Kouzani A.Z., Kaynak A., Khoo S.Y., Norton M., Gates W. 2018. Soil Bulk Density
Estimation Methods: A Review. Pedosphere 28(4): 581-596. DOI: 10.1016/S1002-0160(18)60034-7

Baker T.R., Jones J.P.G., Rendón Thompson O.R., Cuesta R.M.R., Del Castillo D., Aguilar I.C., Torres J., Healey J.R. 2010. How can ecologists help realise the potential of payments for carbon in tropical forest countries? Journal of Applied Ecology 47(6): 1159-1165. DOI: 10.1111/j.1365-2664.2010.01885.x

Barth S.R., Giménez A.M., Joseau M.J., Gauchat M.E., Fassola H.E., 2016. Aboveground biomass allocation of Grevillea robusta A. based on initial planting density. Scientia Forestalis 44(111): 653-664. DOI: 10.18671/scifor.v44n111.11

Bassi A.M., Yudken J.S., Ruth M. 2009. Climate policy impacts on the competitiveness of energy-intensive manufacturing sectors. Energy Policy 37(8): 3052 3060. DOI: 10.1016/j.enpol.2009.03.055

Brockerhoff E.G., Barbaro L., Castagneyrol B., Forrester D.I., Gardiner B., González-Olabarria J.R., Lyver P.O.B., Meurisse N., Oxbrough A., Taki H., Thompson I.D., van der Plas F., Jactel H. 2017. Forest biodiversity, ecosystem functioning and the provision of ecosystem services. Biodiversity and Conservation 26(13): 3005 3035. DOI: 10.1007/s10531-017-1453-2

Brown P. 1998. Climate, biodiversity, and forests: issues and opportunities emerging from the Kyoto protocol. Washington: World Resources Institute. 36 p.

Brown S., Lugo A. 1984. Biomass of Tropical Forests: A New Estimate Based on Forest Volumes. Science 223(4642): 1290-1293. DOI: 10.1126/science. 223.4642 .1290

Cerana J., Wilson M., Pozzolo O., De Battista J.J., Rivarola S., Díaz E. 2005. Relaciones matemáticas entre la resistencia mecánica a la penetración y el contenido hídrico en un Vertisol. In: F.J. Samper Calvete, A. Paz González (Eds.): Estudios de la Zona No Saturada del Suelo. Vol. 7. P. 159-163.

Chagas C.I., Kraemer F.B. 2018. Runoff, soil erosion and contamination of surface water resources by sediments associated with extensive agricultural activities: some elements for its analysis. Ciudad Autónoma de Buenos Aires: Editorial Facultad de Agronomía. 33 p.

Collins M.B., Mitchard E.T.A. 2017. A small subset of protected areas are a highly significant source of carbon emissions. Scientific Reports 7: 41902. DOI: 10.1038/srep41902

Cozzo D. 1979. Arboles forestales, maderas y silvicultura de la Argentina. Buenos Aires: ACME. 289 p.

Davis M.R., Allen R.B., Clinton P.W. 2003. Carbon storage along a stand development sequence in a New Zealand Nothofagus forest. Forest Ecology and Management 177(1-3): 313-321. DOI: 10.1016/S03781127(02)00333-X

de Petre A., Karlin U., Ali S., Reynero N. 2011. Alternativas de sustentabilidad del bosque nativo del Espinal. Area de Captura de Carbono. Argentina: PIARFON. 15 p.

Dixon R.K., Brown S., Houghton R.A., Solomon A.M., Trexler M.C., Wisniewski J. 1994. Carbon Pools and 
Flux of Global Forest Ecosystems. Science 263(5144): 185-190. DOI: 10.1126/science.263.5144.185

FAO. 2007. State of the World's Forests 2007. Rome: FAO. 197 p.

FAO. 2009. State of the World's Forests 2009. Rome: FAO. 175 p.

FAO. 2018. Measuring and modelling soil carbon stocks and stock changes in livestock production systems Guidelines for assessment (Draft for public review). Livestock Environmental Assessment and Performance (LEAP) Partnership. Rome: FAO. 201 p.

Fernandez P.D., Gasparri N.I., Jobbágy E., Mazzini F., Oviedo E., Radrizzani A. 2018. Stock de carbono en vegetación leñosa aérea y su relación con disturbios en sistemas silvopapstoriles del Chaco Seco Argentino. In: IV Congreso Nacional de Sistemas Silvopastoriles. Villa Langostura, Argentina. P. 508-517.

Fragoso-López P.I., Rodríguez-Laguna R., Otazo-Sánchez E.M., González-Ramírez C.A., Valdéz-Lazalde J.R., Cortés-Blobaum H.J., Razo-Zárate R. 2017. Carbon Sequestration in Protected Areas: A Case Study of an Abies religiosa (H.B.K.) Schlecht. et Cham Forest. Forests 8(11): 429-442. DOI: 10.3390/f8110429

Francis J.K. 2000. Estimating Biomass and Carbon Content of Saplings in Puerto Rican Secondary Forests. Caribbean Journal of Science 36: 346-354.

Frangi J., Pérez C., Goya J., Tesón N., Barrera M., Arturi M. 2016. Experimental model of a Eucalyptus grandis plantation in Concordia, Entre Ríos. Bosque. 37(1): 191-204. DOI: 10.4067/S0717-92002016000100018

Franquis F.R., Infante A.M. 2003. Los Bosques y su Importancia para el Suministro de Servicios Ambientales. Félix R. Franquis; Angel M. Infante. Revista Forestal Latinoamericana 18: 17-30.

Freibauer A., Rounsevell M.D.A., Smith P., Verhagen J. 2004. Carbon sequestration in the agricultural soils of Europe. Geoderma 122(1): 1-23. DOI: 10.1016/j. geoderma.2004.01.021

Gaillard de Benitez C., Pece M., Juárez de Galíndez M., Maldonado A., Acosta V.H., Gómez A. 2014. Aerial biomass of individuals of Quebracho blanco (Aspidosperma quebracho-blanco) in two towns (localitites) of the Dry Chaco Park. Quebracho 9: 115-127.

Gasparri I., Manghi E. 2004. Estimación de volumen, biomasa y contenido de carbono de las regiones forestales argentinas. Buenos Aires: Secretaria de Desarrollo y Ambiente Sustentable. 26 p.

Gasparri N.I., Grau H.R., Manghi E. 2008. Carbon Pools and Emissions from Deforestation in Extra-Tropical Forests of Northern Argentina Between 1900 and 2005. Ecosystems 11(8): 1247-1261. DOI: 10.1007/s10021-008-9190-8

Gaveau D.L.A., Sheil D., Husnayaen, Salim M.A., Arjasakusuma S., Ancrenaz M., Pacheco P., Meijaard E. 2016. Rapid conversions and avoided deforestation: examining four decades of industrial plantation expansion in Borneo. Scientific Reports 6: 32017. DOI: 10.1038/srep32017

Gifford R. 2000. Carbon contens of above-ground tissues of forest and woodland trees. Australian Greenhouse
Office. National Carbon Accounting System Technical Report No.22. Canberra: Australian Greenhouse Office. 17 p.

Hansen M.C., Potapov P.V., Moore R., Hancher M., Turubanova S.A., Tyukavina A., Thau D., Stehman S.V., Goetz S.J., Loveland T.R., Kommareddy A., Egorov A., Chini L., Justice C.O., Townshend J.R.G. 2013. High-resolution global maps of 21 st-century forest cover change. Science 342(6160): 850-853. DOI: 10.1126/science. 1244693

Hedde M., Aubert M., Decaëns T., Bureau F. 2008. Dynamics of soil carbon in a beechwood chronosequence forest. Forest Ecology and Management 255(1): 193 202. DOI: 10.1016/j.foreco.2007.09.004

Houghton R.A. 2003. Why are estimates of the terrestrial carbon balance so different? Global Change Biology 9(4): 500-509. DOI: 10.1016/j.foreco.2007.09.004

IPCC. 1995. Greenhouse Gas Inventory Reference Manual. IPCC Guidelines for National Greenhouse Gas Inventories. London, England. 274 p.

IPCC. 2014. Climate Change 2014: Synthesis Report. Contribution of Working Groups I, II and III to the Fifth Assessment Report of the Intergovernmental Panel on Climate Change. Geneva, Switzerland: IPCC. $151 \mathrm{p}$.

Jackson M. 1964. Análisis químico de suelos. Barcelona, España: Omega SA. 662 p.

Janzen H.H. 2004. Carbon cycling in earth systems - a soil science perspective. Agriculture, Ecosystems and Environment 104(3): 399-417. DOI: 10.1016/j.agee.2004.01.040

Lucero Ignamarca A., Muñoz Sáez F., Cancino J., Sotomayor Garreton A., Dube F., Villarroel Muñoz A., Sáez Carrillo K. 2018. Biomass function for Acacia caven (Mol.) Mol. distributed in the dry land areas of south central Chile. Revista de la Facultad de Ciencias Agrarias 50(2): 187-201.

Malanima P. 2006. Energy crisis and growth 1650-1850: the European deviation in a comparative perspective. Journal of Global History 1(1): 101-121. DOI: 10.1017/S1740022806000064

Malhi Y., Baldocchi D.D., Jarvis P.G. 1999. The carbon balance of tropical, temperate and boreal forests. Plant, Cell and Environment 22(6): 715-740. DOI: 10.1046/j.1365-3040.1999.00453.x

Manrique S., Franco J. 2012. Cultivos agricolas y su rol como reservorios de carbono y fuentes de energía. Avances en Energia Renovable y Medio Ambiente 16: 1-8.

Manrique S., Franco J., Nuñez V., Seghezzo L. 2009. Estimación de densidad de biomasa aerea en ecosistemas naturales de la provincia de Salta. Avances en Energías Renovables y Medio Ambiente 13: 37-45.

Martin A.R., Thomas S.C. 2011. A Reassessment of Carbon Content in Tropical Trees. PLoS ONE 6(8): e23533. DOI: 10.1371/journal.pone.0023533

Matteuci S., Colma A. 1982. Metodología para el estudio de la vegetación. Washignton, USA: General Secretariat of the Organization of American States. 198 p.

Melillo J.M., Lu X., Kicklighter D.W., Reilly J.M., Cai Y., Sokolov A.P. 2016. Protected areas' role in climate- 
change mitigation. Ambio 45(2): 133-145. DOI: 10.1007/s13280-015-0693-1

Metz B., Davidson O., Swart R., Pan J. 2001. Climate Change 2001. Mitigation. Contribution of Working Group III to the Third Assessment Report of the Intergovernmental Panel on Climate Change (IPCC). Cambridge, England. 231 p.

Monreal C.M., Etchevers J.D., Acosta M., Hidalgo C., Padilla J., López R.M., Jiménez L., Velázquez A. 2005. A method for measuring above- and below-ground $\mathrm{C}$ stocks in hillside landscapes. Canadian Journal of Soil Science 85(4): 523-530. DOI: 10.4141/S04-086

Mori A.S., Lertzman K.P., Gustafsson L. 2017. Biodiversity and ecosystem services in forest ecosystems: a research agenda for applied forest ecology. Journal of Applied Ecology 54(1): 12-27. DOI: 10.1111/1365-2664.12669

Muñoz C., Ovalle C., Zagal E. 2007. Distribution of soil organic carbon stock in an alfisol profile in Mediterranean Chilean ecosystems. Journal of Soil Science and Plant Nutrition 7(1): 15-27.

Muzzachiodi N., Sabattini R.A. 2019. Descripción de la fauna asociada y su nivel de conservación. Corredores faunísticos. In: J.A. Sabattini, R.A. Sabattini (Eds.): Área natural protegida reserva de usos múltiples Estancia «El Carayá»: Producción, conservación y recuperación de ecosistemas en el Espinal Argentino. Rafaela, Argentina. P. 95-131.

Nauclér T., Enkvist P. 2009. Pathways to a Low-Carbon Economy: Version 2 of the global greenhouse gas abatement cost curve. McKinsey and Company. 98 p.

Nelson D.W., Sommers L.E. 1982. Total carbon, organic carbon and organic matter. In: A.L. Page (Ed.): Methods of Soil Analysis: Part 2 Chemical and Microbiological Properties, 9.2.2, Second Edition. Madison, Wisconsin, USA: American Society of Agronomy and Soil Science Society of America. P. 539-579. DOI: 10.2134/agronmonogr9.2.2ed.c29

Nogueira E.M., Yanai A.M., de Vasconcelos S.S., de Alencastro Graça P.M.L., Fearnside P.M. 2018. Carbon stocks and losses to deforestation in protected areas in Brazilian Amazonia. Regional Environmental Change 18(1): 261-270. DOI: 10.1007/s10113-017-1198-1

Odum E.P. 1969. The Strategy of Ecosystem Development. Science 164(3877): 262-270. DOI: 10.1126/ science.164.3877.262

Ontiveros A., Manrique S., Franco J., Díaz R., Barranco N. 2015. Biomasa y stock de carbono en la Reserva de Campo Alegre, La Caldera, provincia de Salta. Avances en Energia Renovable y Medio Ambiente 19: 1-11.

Oyarzabal M., Clavijo J., Oakley L., Biganzoli F., Tognetti P., Barberis I., Maturo H.M., Aragón R., Campanello P.I., Prado D., Oesterheld M., León R.J.C. 2018. Vegetation units of Argentina. Ecología Austral 28(1): 40-63. DOI: 10.25260/EA.18.28.1.0.399

Pan Y., Birdsey R.A., Fang J., Houghton R., Kauppi P.E., Kurz W.A., Phillips O.L., Shvidenko A., Lewis S.L., Canadell J.G., Ciais P., Jackson R.B., Pacala S.W., McGuire A.D., Piao S., Rautiainen A., Sitch S., Hayes D. 2011. A Large and Persistent Carbon Sink in the
World's Forests. Science 333(6045): 988-993. DOI: 10.1126/science. 1201609

Pardos J.A. 2010. Los ecosistemas forestales y el secuestro de carbono ante el calentamiento global. Madrid, España. 253 p.

Peri P.L., Gargaglione V., Martínez Pastur G., Lencinas M.V. 2010. Carbon accumulation along a stand development sequence of Nothofagus antarctica forests across a gradient in site quality in Southern Patagonia. Forest Ecology and Management 260(2): 229237. DOI: $10.1016 /$ j.foreco.2010.04.027

Peri P.L., Ormachea S., Martinez P.G., Lencinas M.V. 2013. Inventario provincial del contenido de carbono en bosques nativos de ñire en Santa Cruz. In: Actas $4^{\text {to }}$ Congreso Forestal Argentino y Latinoamericano. Misiones: Asociación Forestal Argentina. P. 1-10.

Risio Allione L. 2012. Cuantificación de biomasa y carbono en bosques nativos de Prosopis caldenia (Burkart) en la Pampa semiárida. Msc Thesis. Argentina. 71 p.

Roberts C.M., O’Leary B.C., Hawkins J.P. 2020. Climate change mitigation and nature conservation both require higher protected area targets. Philosophical Transactions of the Royal Society B: Biological Sciences 375(1794): 20190121. DOI: 10.1098/rstb.2019.0121

Rojas A., Saluso J.H. 1987. Informe Climático de la Provincia de Entre Ríos. Publicación Técnica No.14. INTA EEA Paraná. Instituto Nacional de Tecnología Agropecuaria. $26 \mathrm{p}$.

Sabattini J.A. 2015. Land cover and land use changes of native forests categories: the case of the Atencio District, Argentina, in the period from 1984 to 2013. Forest Systems 24(2): e028. DOI: 10.5424/fs/2015242-06680

Sabattini J.A., Sabattini R.A. 2018. Sucesión vegetal y restauración ecológica. Revista Científica Agropecuaria 22(1-2): 31-53.

Sabattini J.A., Sabattini R.A. 2019. Área natural protegida reserva de usos múltiples Estancia «El Carayá»: Producción, conservación y recuperación de ecosistemas en el Espinal Argentino. Rafaela, Argentina: SocialMedia. 134 p.

Sabattini J.A., Sabattini R.A., Ledesma S. 2015a. Characterization of Native Forest in North Central Entre Rios (Argentina). Agrociencia 19(2): 8-16.

Sabattini J.A., Boschetti N.G., Sabattini R.A., Quintero C.E., Hernandez J.P., Befani R. 2015b. Vegetation units of native forest, according to soil conditions (Entre Ríos, Argentina). Avances en Investigación Agropecuaria 19: 79-96.

Sabattini J.A., Sabattini R.A., Urteaga Omar A.F., Bacigalupo M., Cian J.C., Sabattini I.A., Dopazo V.M. 2019. Recovery of the natural grassland in a degraded native forest of the Argentine Espinal through aerial chemical control of shrubs. Investigación Agraria 12(1): 93-107. DOI: 10.18004/ investig.agrar.2019.diciembre.93-107

Sabattini R.A., Bongiovanni S.N. 2019. Caracterización del medio natural y socioeconomico. In: J.A. Sabattini, R.A. Sabattini (Eds.): Área natural protegida reserva de usos múltiples Estancia «El Carayá»: Producción, conservación y recuperación de ecosistemas en el Espinal Argentino. Rafaela, Argentina. P. 31-49. 
Sabattini R.A., Wilson M.G., Muzzachiodi N., Dorsch A.F. 1999. Guide to characterize the agroecosystems of northern center Entre Ríos. Revista Cientifica Agropecuaria 3: 7-19.

Sabattini R.A., Muzzachiodi N., Dopazo V., Dorsch A.F., Micheloud L., Serro C., Garcia A., Cencig G. 2003. Rotational grazing implementation in native forest of Feliciano (Entre Ríos). Revista Cientifica Agropecuaria 7(1): 87-94.

Sabattini R.A., Boschetti G.N., Quintero C., Hernandez J.P., Befani R., Sabattini I.A., Cian J.C., Sabattini J.A., Krüger A., Arbello P. 2013. Zonificación: diagnóstico estado de los montes nativos y tipo de suelos. Estancia El Carayá. Oro Verde, Argentina: Facultad de Ciencias Agropecuarias. 40 p.

Sabattini R.A., Anglada M.M., Sabattini I.A., Cian J.C., Bacigalupo M., Krüger A., Sabattini J.A., Heinze D., Lindt M. 2014. Recuperación de un monte nativo degradado con la utilización de la limpieza quimica aérea en la Estancia El Caraya: Lotes 4 Sureste A (2012-2013) y B (2013-2014), y Lote 51 (2013-2014). Argentina: Facultad de Ciencias Agropecuarias, UNER. 48 p.

Sabattini R.A., Sabattini J.A., Boschetti N.G., Quintero C., Cian J.C., Befani R., Hernandez J.P., Urteaga Omar F., Sabattini I.A. 2019. Caracterización de la vegetación, unidades ambientales, y asociaciones edáficas. In: J.A. Sabattini, R.A. Sabattini (Eds.): Área natural protegida reserva de usos múltiples Estancia «El Carayá»: Producción, conservación y recuperación de ecosistemas en el Espinal Argentino. Rafaela, Argentina. P. 51-94.

SADSN (Secretaría de Ambiente y Desarrollo Sustentable de la Nación). 2015. Tercera comunicación nacional de la República Argentina a la Convención Maro de las Naciones Unidas sobre el Cambio Climatico. Available from: https://unfecc.int/resource/docs/natc/argnc3s.pdf

Sione S., Wilson M.G., Andrade H.J., Rosenberger L.J., Sasal M.C., Gabioud E.A. 2018. Carbono almacenado en la biomasa aérea de los bosques nativos del espinal (Argentina). In: Resumenes Comunicacionales Orales VIII Congreso sobre uso y manejo del suelo. Coruña, España. 32 p.

Sione S.M.J., Andrade-Castañeda H.J., Ledesma S.G., Rosenberger L.J., Oszust J.D., Wilson M.G. 2019. Aerial biomass allometric models for Prosopis affinis Spreng. in native Espinal forests of Argentina. Revista Brasileira de Engenharia Agrícola e Ambiental 23(6): 467-473. DOI: 10.1590/1807-1929/agriambi.v23n6p467-473

Soares C.P.B., Oliveira M.L.R.d. 2002. Equations for estimating the amount of carbon in the aerial parts of eucalypt trees in Viçosa, MG, Brazil. Revista Árvore 26(5): 533-539. DOI: 10.1590/S0100-67622002000500002

Soares-Filho B.S., Nepstad D.C., Curran L.M., Cerqueira G.C., Garcia R.A., Ramos C.A., Voll E., McDonald A., Lefebvre P., Schlesinger P. 2006. Modelling conservation in the Amazon basin. Nature 440(7083): 520-523. DOI: 10.1038/nature04389

Soares-Filho B., Moutinho P., Nepstad D., Anderson A., Rodrigues H., Garcia R., Dietzsch L., Merry F., Bowman M., Hissa L., Silvestrini R., Maretti C. 2010. Role of
Brazilian Amazon protected areas in climate change mitigation. Proceedings of the National Academy of Sciences of the United States of America 107(24): 10821-10826. DOI: 10.1073/pnas.0913048107

Soil Mapping Plan. 1986. Carta de Suelos de la República Argentina. Departamento Feliciano, Provincia de Entre Ríos. Convenio INTA Gobierno de Entre Ríos. 72 p.

Taiz L., Zeiger E. 1998. Plant Physiology. Sunderland, Massachussets: Sinauer Associates Inc. 674 p.

UNEP-WCMC and IUCN. 2016. Protected Planet Report 2016: How protected areas contribute to achieving global targets for biodiversity. Cambridge, UK; Gland, Switzerland: Centre UWCM. 73 p.

Urdapilleta A. 2018. Cuantificación del carbono almacenado en la biomasa arbórea en un predio ubicado en la región del Parque Chaqueño húmedo, Argentina. Ingeniero Forestal Thesis. Argentina: Universidad Nacional de la Plata. 63 p.

Vega J., Martiarena R. 2010. Carbono almacenado en la biomasa aérea de plantaciones de araucaria (Araucaria angustifolia Bert. O. Ktze.). Revista Ciencia y Tecnologia 13(1): 79-86.

Venter O., Sanderson E.W., Magrach A., Allan J.R., Beher J., Jones K.R., Possingham H.P., Laurance W.F., Wood P., Fekete B.M., Levy M.A., Watson J.E.M. 2016. Sixteen years of change in the global terrestrial human footprint and implications for biodiversity conservation. Nature Communications 7: 12558. DOI: $10.1038 /$ ncomms 12558

Vicente G., Engle P., Jaubertie C. 2011. Valorización económica del carbono secuestrado en el distrito del Ñandubay, Entre Ríos, como herramienta para un ordenamiento territorial. In: P. Laterra, E. Jobbagy, J.M. Paruelo (Eds.): Valoración de Servicios Ecosistémicos: Conceptos, herramientas y aplicaciones para el ordenamiento territorial. Argentina: Ediciones INTA. P. 581-599.

Watson J.E.M., Evans T., Venter O., Williams B., Tulloch A., Stewart C., Thompson I., Ray J.C., Murray K., Salazar A., McAlpine C., Potapov P., Walston J., Robinson J.G., Painter M., Wilkie D., Filardi C., Laurance W.F., Houghton R.A., Maxwell S., Grantham H., Samper C., Wang S., Laestadius L., Runting R.K., Silva-Chávez G.A., Ervin J., Lindenmayer D. 2018. The exceptional value of intact forest ecosystems. Nature Ecology and Evolution 2(4): 599-610. DOI: 10.1038/s41559-018-0490-x

Whitehead D., Baisden T., Beare M., Campbell D., Curtin D., Davis M., Hedley C., Hedley M., Jones H., Kelliher F., Saggar S., Shipper L. 2012. Review of soil carbon measurement methodologies and technologies, including nature and intensity of sampling, their uncertainties and costs. Technical Paper by Landcare Research No.2012/36. Ministry for Primary Industries. 92 p.

Wilson M.G. 2017. Manual de indicadores de calidad del suelo para las ecorregiones de Argentina. Entre Ríos: Ediciones INTA. 294 p.

Wilson M.G., Sabattini R. 2001. Sustainability of native forest agroecosystems in Entre Ríos, Argentina: review and conceptual model. Revista Facultad de Agronomia 21(2): 117-128. 
ЗАПАСЫ УГЛЕРОДА В СУБТРОПИЧЕСКИХ КОРЕННЫХ ЛЕСАХ НА ОСОБО ОХРАНЯЕМОЙ ПРИРОДНОЙ ТЕРРИТОРИИ ЮЖНОЙ АМЕРИКИ

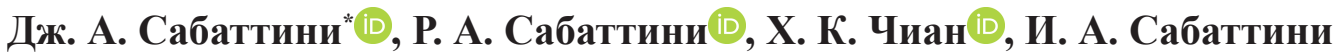 \\ Национальный университет Энтре Риос, Аргентина \\ *e-mail: julian.sabattini@fca.uner.edu.ar
}

\begin{abstract}
В лесных системах возможно улавливать углерод, выделяемый в результате промышленной деятельности, несмотря на то, что глобальное сокращение лесов в последнее время значительно возросло. Особо охраняемые природные территории (ООПТ) вносят значительный вклад в смягчение негативных последствий изменения климата. Целью данного исследования было оценить запасы углерода в различных типах коренных субтропических лесов на ООПТ «Эстансия Эль-Карая» (далее - ООПТ «Эль-Карая»), расположенной на Месопотамском хребте. Исследования проводились в провинции Энтре Риос (Аргентина). Мы оценили запасы углерода в почве и в таких компонентах экосистемы, как травы, кустарники и деревья в пяти различных средах, покрытых коренными лесами в качестве преобладающего биома. Компонент почвы был представлен $81 \%$ запасов углерода в коренных лесах, в то время как оставшаяся доля распределяется между деревьями (11\%), кустарниками (6\%) и травянистой

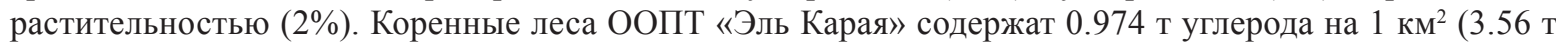
$\mathrm{CO}_{2}$ на 1 км²). Это на $39.4 \%$ меньше, чем в среднем в мире для этой природоохранной категории. Эти различия связаны с высокой неоднородностью природной среды в мире ввиду очень разнообразных экологических условий. Надлежащие методы управления коренными субтропическими лесами Месопотамского хребта в значительной степени способствуют сокращению выбросов углерода в атмосферу. Применение методов управления лесным хозяйством на ООПТ позволяет получить устойчивые леса, которые максимально раскрывают потенциал этой территории.
\end{abstract}

Ключевые слова: поглощение углерода, изменение климата, экосистемные услуги, Эль-Карая, общественная политика, охраняемый лес, сокращение выбросов 